日作紀（Jpn. J. Crop Sci.） $77 （ 2 ） ： 229-232 （ 2008 ）$

\title{
連載ミニレビュー
}

\section{作物の形態研究法：マクロからミクロまで 分げつについて}

\author{
大江真道 \\ (大阪府立大学大学院生命環境科学研究科)
}

イネ科作物の分枝は分げつと呼ばれる，植物学的には側芽が発達した分枝であるが，わが国ではこのように呼ばれ，学 術用語として位置づけられている。

分げつの出現や成長，つまり分げつ性は種や品種によって特徵があり，その特徵が草型を特徴づけている．また，作物 生産に扔いては子実収量, バイオマス生産に直結する要素で, その消長は栽培の良否, 施肥の適期, 生育相を知る主要な 手段として活用されている。一方, 研究分野においても, その推移, 規則性, 他分げつとの相互関係の解析は, 品種の特性, 生育の特性, 生育の良否を知る手段として重要な意味を持つ. 分げつに関しては, 分化発達, 種や品種と分枝構造との関係, 環境条件や栽培条件との関係など，興味深い側面を多々含むが，本稿では主にイネの分げつについて，基本となる表記や 呼称，生育の様相，規則性，調査方法を述べることとした．

\section{1. 分げつについて}

\section{（1）分げつの種類と表記のしかた}

イネ科植物では，主稈上の節に分化した分げつを 1 次分 げつ, 1 次分げつの節に分化した分げつを 2 次分げつ, 2 次分げつの節に分化した分げつを 3 次分げつと呼んでい る。分げつの表記には片山（1951）が用いた表記方法が一 般に広く利用されている。この表記では第 $\mathrm{n}$ 節から出現す る 1 次分げつは $\mathrm{n}$, 第 $\mathrm{n}$ 節の 1 次分げつの第 $\mathrm{m}$ 節から出現 する 2 次分げつは $\mathrm{nm}$, その 2 次分げつの $\mathrm{k}$ 節から出現す る 3 次分げつは $\mathrm{nmk}$ として示される（nmk は 322 のよう に算用数字で示す) (第 1 図)。それぞれの分げつの葉数 $(l)$ は, $l / \mathrm{n}, l / \mathrm{nm}, l / \mathrm{nmk}$ と表記される(例 : 3/322).

次に tiller（“分げつ”英用語）の頭文字 Tを付して 1 次 分げつ, 2 次分げつ, 3 次分げつをそれぞれ Tn, Tn-m, Tn-m-k と表す後藤・星川（1988）の方法もよく用いられ ている(第 1 図)，片山の表記では 10 節を超える上位の節 からも分げつを出す植物種を扱う場合には，ローマ数字や フォントサイズの変更を要したが (例：XI1，111），後藤・ 星川の方法ではその必要が無く具合が良い.

\section{（2）分げつと分げつ芽}

分げつは，母茎の節にできる分げつ芽が発達したもので ある。一般に，節に分化した分げつは葉鞘内で成長中は分 げつ芽と呼ばれ，葉鞘外へ出現した時点を境にして分げつ と呼ばれて区別される，外見で判断できるか否かが境とな り，確認できた時点を分げつと呼び，カウントすることは， 栽培や研究の上で合理的である。なお, 用語“分げつ”は, 分げつ芽を含んだ用語として広義に用いる場合，分げつ出
現の様相を意味して用いる場合もある.

\section{（3）有効分げつと無効分げつ}

穂を着生する分げつを有効分げつ，生育途中で立ち枯れ る分げつを無効分げつと呼ぶ. 分げつ盛期（有効分げつ数 決定期頃）以降に出現する高位節や高次の分げつは無効化 しやすい. 外部形態からは, 最高分げつ期 1 週目ころの分 げつの草丈が株の最長稈と比較して 3 分の 2 に満たないも のが無効化するとされ（星川 1975），生育からは，最高分 げつ期頃の出葉が停滞するものが無効化するとされている （松島 1959）。なお，出現した分げつ総数に占める有効分 げつの割合を有効分げつ（有効茎）歩合と呼ぶが，無効分 げつを抑えて有効分げつ歩合を高めた生育（目標とする穂 数の確保が前提) は, 収量, 肥料の利用率, 群落環境のう えでも優れる。このような生育を実現できる水稲の生育調 節技術には, 古くは青森県農業試験場で開発された深層追 肥技術にみられる追肥重点施肥（三本 1968），他には分げ つ盛期からの深水管理（大江・三本 2002）などがある.

\section{2. 分げつの出方}

\section{（1）出現部位と出現の規則性}

栽培イネの分げつは，特別な栽培型のものを除いて分げ つ節と呼ばれる不伸長茎部の各節の葉腋部から栄養生長期 に出現する.ささらにその分げつの不伸長茎部の各節の葉腋 部からも分げつ（2 次分げつ）が出現し, さらにその分げ つからも分げつ（3 次分げつ）が出現する．分げつの出現 には秩序があり，主秙の葉の抽出と時期的に一定の規則性 を持つ。これは同伸葉同伸分げつ理論と呼ばれ，その標準 株に従えば，主稈のある葉が抽出したときに，その 3 枚下 


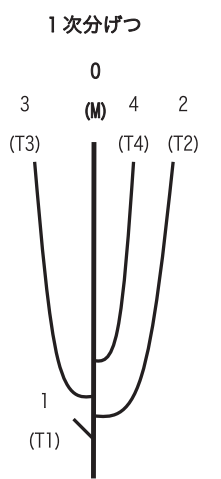

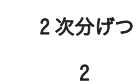

(T2)

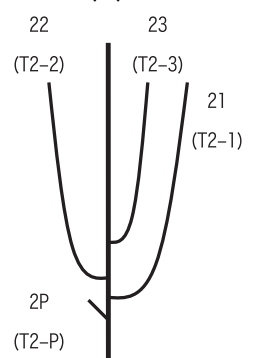

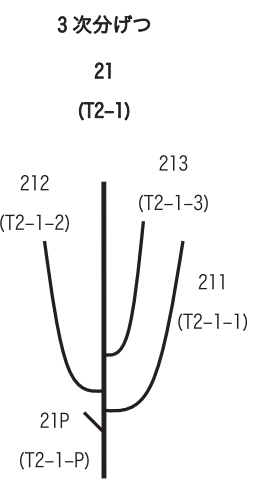

第 1 図 分げつの種類と表記の方法

片山による表記のしかた（上）と後藤・星川による表記のし かた（括弧内），P：プロフィル，2次分げつ，3次分げつは 主秙の第 2 節に由来する分げつで代表させた。

位の葉の葉腋から分げつの第 1 葉が現れる（片山 1951）. この理論は主秙と 1 次分げつのみならず， 1 次分げつと 2 次分げつ, 2 次分げつと 3 次分げつ間にも認められるため, ある葉齢に扔ける出現分げつ, 各分げつの葉数を知ること が可能である，ただし，生育に伴うズレや最高分げつ期頃 以降の規則性の乱れが早くから報告され（松島 1959, 佐 藤 1952), その後理論との差の詳細な検証が松葉（1988） によって，また差の影響を除去した解析法が後藤・星川に よって提案されている (1988)，また，分げつの規則性の みならず，出現以前の分げつ，つまり分げつ芽についても 主程との相互成長の解析が花田 (1977), 関谷 (1977), 松 葉（1996）によって進められてきた.

\section{（2）出現しない分げつ}

分げつ節に分化した分げつ芽が栄養生長中に全て出現す るとなれば，理論的にはかなり多数の分げつが出現するは ずである，栽培条件が良好であっても実際には主稈の第 1 節からの分げつは休眠しやすく, 2 次， 3 次分げつではプ ロフィル節からの分げつも出現することは少ない。 また， 株同士や株内の干渉, 生理的な強弱, 移植深, 湛水深, 栽 植密度, 移植時のストレス（植え傷み）も影響し, 出現数 はさらに少なくなる。

\section{（3）他のイネ科植物にみられる特徵的な出現の例}

栽培イネの分げつは先に述べたように, 分げつ節と呼ば れる不伸長茎部から主に出現する。しかし, 一部のイネ科 雑草では分げつを伸長茎部からも盛んに出現させるものが ある，著者はノビエを観察し，栽培イネと同様に分げつを 主に不伸長茎部から出現させるものと, 伸長茎部からも出 現させる二つの草型について，それぞれをイネ型分げつと 非イネ型分げつとした（大江・山口 2000）。イネ型分げつ のノビエでは 1 株あたりの総分げつ数は 15 本ほど, 伸長 茎部の分げつはまれ（総分げつ数に占める割合 7\%）で, 栽培イネと同様に高次・高位節の分げつは無効化していた。

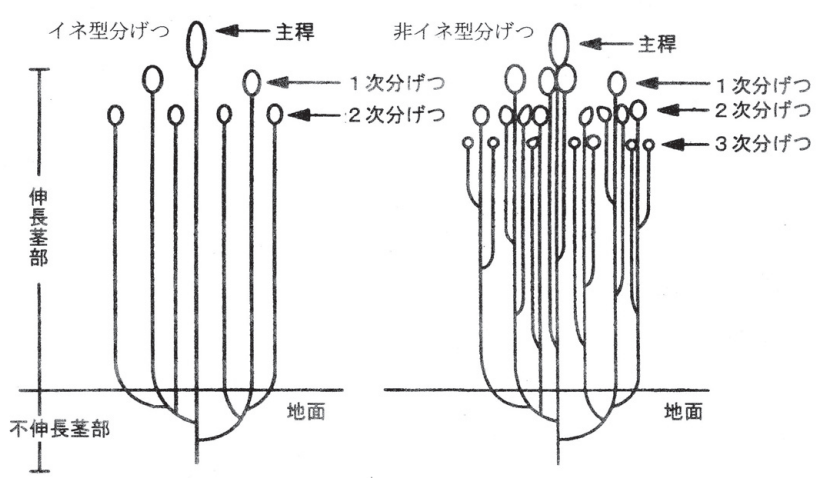

第 2 図 イネ型分げつと非イネ型分げつの模式図（大江・山口 2000）

一方, 非イネ型分げつの 1 株あたりの総分げつ数は 45 本 と非常に多く, 伸長茎部からの分げつの総分げつ数に占め る割合が $56 \%$ と非常に高かった，外部形態的にみると，伸 長節からの分げつは空中分げつと呼ぶに相応しい. イネ個 体群の中で雑草として生きるノビエの戦略とも言える特徴 的な分げつ性は，生産性の点のみならず群落の空間利用の 点からも興味深い (第 2 図).

\section{3. 分げつの調査}

\section{(1) 調査の方法}

分げつ調査の方法は簡便なものから手間のかかるものま で多様である. 出現には規則性があり, 数学的センスがあ れば掘り下げて調査したくなるが, 詳細になればなるほど 生育調査やその後の解析に占める時間・労力が多大になる ので必要とする情報, 精度に応じて使い分けるのが良い. 個々の分げつの識別はせずに，一定間隔ごとに分げつの出 現数を数える方法は最も簡便な方法であり, 品種による茎 数増加の特徵の違い, 生育の良否, 処理に対する生育応答 の特徴を判断する場合には十分である。これだけでも試験 地に扔ける期待生育曲線に対比でき, それをもとに試験年 における生育の遅速, 生育段階の把握が可能となる。

次に，手間はかかるが株を構成する個々の分げつについ て, 出現した分げつの葉数増加の遅速, 総葉数, 分げつご との出現日, 出現率などを求める詳細な調査がある。葉数 増加の遅速, 総葉数, 出現日の早晚の調查は, 分げつの有 効・無効化の予測, 個々の分げつの生産力を解析的に検討 する研究に有効である。 また, 個々の分げつについての出 現率の調査は, 草型の異なる品種の構成分げつを求める場 合に有効である。一方, 各分げつの出現率を調查し, 出現 率の劣った分げつから株がストレスを受けた時期を推測す ることができる．分げつには外的ストレスによって最も影 響を受けやすい生育段階があり，母茎の葉鞘からまもなく 出現に至る生育段階では最も影響を受けて生育を停止しゃ すく, それより前の分化直後のもの, 既に出現した生育段 階のものは影響の程度が小さく生長の停止までにはいたら ない（西川・花田 1959, 大江ら 1994）。例えば 3 号分 げつの出現が大きく抑制されたならば，主茎の 5 葉展開終 


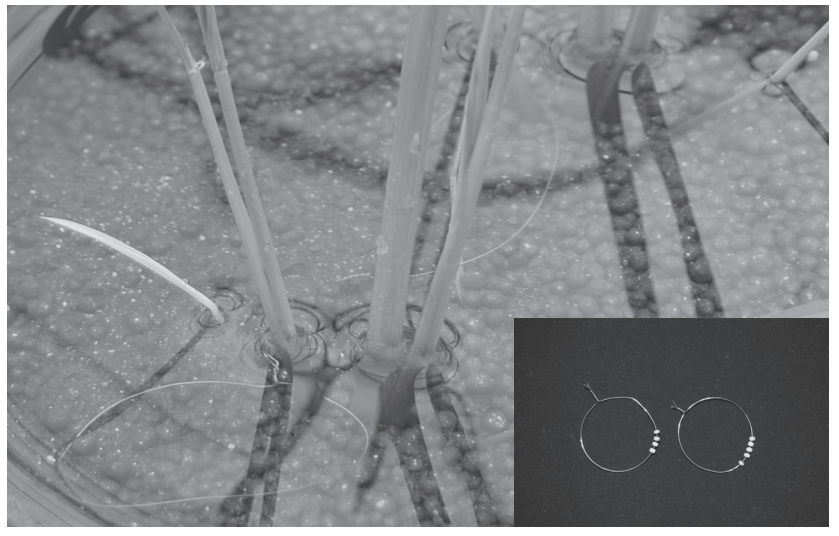

第 3 図＼cjkstart分げつリングの装着

右下：作成したリング。リングに通したビーズ（数）で分げ つを区別.

了時から 6 葉抽出開始時期ころに低温, 植え傷み, 水不足 などの外的ストレスを受けたと推察できる.

\section{（2）分げつ識別の工夫}

生育の進行に伴い, 個々の分げつを取り違えることなく 区別するのは困難である。このため一般には分げつの種類, 葉位, 出現日を油性ペンを用いて分げつの葉身に直接マー キングする手法が用いられる。葉が枯死しても風乾後でも 識別は案外容易である。簡便な手法としては, 著者の研究 グループでは, 分げつリングと呼ぶエナメル線の識別リン グを作成し，主稈から分げつが出現次第，輪投げの要領で 分げつにリングを通す方法を採っている。主秙からの分げ つ（1 次分げつ）を, 2 次, 3 次分げつひとまとまりのグルー プとして，くくるが，これだけでもその後の識別は容易に なる (第 3 困).

なお，後になって分げつの区別の必要が生じた時には次 の手順に従うとよい. まず主秙と 1 次分げつの区別をする ために，出現中の主稈葉から下位の主稈葉に向かい主稈の 葉に葉位のマーキングを行う。主稈の葉とその葉腋から出 現した分げつの葉の区別が明瞭でない場合もあるが，主稈 の葉のほうが粗剛で葉色がやや薄いのでおおよそ区別がつ く、また，判る範囲でたどればよい，次に $\mathrm{n}-3$ の規則性 に準じて主稈の抽出葉から 3 枚下位の葉を目安に最も若い 1 次分げつの出現を確認し, 順次下位節へ向かって 1 次分 げつをたどる。主稈の上位の節から下位へたどれば分げつ の葉数は約 1 枚ずつ増加するので，各分げつの出葉中の最 上位葉の葉位から各分げつの葉数 (葉龄) が判る。なお, $\mathrm{n}-3$ の規則性から葉を 4 枚以上持つ分げつからはさらに 分げつが生じるので, 下位の節では 2 次, 3 次分げつの出 現に注意を払う必要がある。調査時に同伸葉同伸分げつ理 論にもとづいて，あらかじめ予想される出現分げつとその 葉数を記した表を用意しているとより区別しやすい.また， 調査時の主稈の葉位が不明であった場合には，とりあえず 暫定的な葉位（例 : $\mathrm{n}, \mathrm{n}-1, \mathrm{n}-2, \cdots)$ を割り振り，止
葉が出現したら当該試験地の供試品種における例年の止葉 葉位をもとにあらためて葉位を割り振れば良い。

\section{（3）分げつ研究用個体の育成における留意点}

分げつ性を対象とした試験では，供試材料の揃いに気を つけ分げつ性が乱れることがないように育成する必要があ る.イネの分げつは通常主稈の第 2 節から出現を開始する が，直播して育てた場合でも管理に起因すると考えられる 影響で，2 節分げつを欠く個体が混じることがある.さら に移植では，2，3，4節の分げつの全てや一部に休眠が生 じたり，葉数に下位節の分げつとの逆転現象が生じる場合 がある，最初の影響は小さくても，生育に伴って分げつ数 や葉数に認められる差が個体間で大きくなり解析を困難に する。

分げつを含めて生育をそろえるための工夫として，著者 の研究グループでは, ポット育苗箱（みのる産業株式会社） を用いて苗を育成し供試している，集約的な管理を行える ためにそろいが良く，苗取りによる断根が生じないために 植え傷みが無く，移植による一部の分げつの休眠や生育の 乱れは生じにくい.なお，育苗期間が長期の場合には個体 同士の干渉が生じないように1列おきに種子の置床方向を そろえて播種すると良い. その他の留意点として，複数人 で播種，移植すると播種深度，移植深度がまちまちになり やすく，その影響が出る。これを避けるためには，作業を 一人で行うことが望ましいが, 複数人で行う際には植えつ け深度の目安にできるものを人数分用意し，揃うようにす ると良い。

\section{まとめ 一作物生産における分げつ調査, 分げつ研究一}

分げつ性は種や品種固有の特性であるが，一方で肥培管 理, 環境による変動も無視できない。分げつ性は子実収量 の多少, バイオマス生産量に密接に影響を及ぼすことから, その性質, 変化をとらえる調査・解析手法は作物生産を良 好に維持するうえで重要な意味をもつ。とくにわが国で精 力的に進められた主稈と分げつ, 分げつどうしの相互生長 における詳細な観察や解析的研究は他に類をみないもので ある。片山（1951）は自身の研究の集大成となる著書『稲・ 麦の分菜研究 - 稲・麦の分葟秩序に関する研究 -』の中で, 従前の分げつに関する試験研究のすべてが永く「分げつ数」 を対象としたものであったことを指摘し，「元々性能がそ れぞれ異なる各種の分菜から構成されている分临数を，何 の区別もなく，一緒くたに取り扱っている以上，これらに よって収量の多少の由来を，明快に説明する事ができない のは当然であろう」として, 分げつ識別の重要性を説いて いる。ささらに、「ただ識別できるだけでは，実用的な効果 はない」と述べ，識別した分げつと主茥との間に秩序を見 いだす必要があること，そしてその秩序は，「簡単明瞭な もので，何人も自由に利用し得るものである事が望ましい」 として, 分げつ研究の理念を示している。片山の理論と研 
究理念は, わが国の分げつ研究にあらたな展開をもたらし たと考える。

片山に始まった分げつ発育の解析的研究が，その後さら にその誤差の解析や誤差の取り扱いを対象にするまでに発 展したのは, わが国に㧍ける水稲の研究や栽培では, 理想 とする草型にこだわった品種の選択や育成, 確保する分げ つの性質にもこだわった緻密な増収技術が発展し, その際 に品種の性質や技術の良否を定量的に評価できる適切な物 差しが必要だったからと考える。分げつ調査から得られる データは大変シンプルだが, 多くの先輩の努力と業績に よって, 得られたデー夕は意義深いものへと変化する。こ

のことに鑑みると，作物学における形態研究の歴史，作物 研究における形態学の重要性についてはあらためて感慨深 いものを感じる.

\section{引用文献}

後藤雄佐・星川清親 1988. 水稲の分げつ性に関する研究. 第 1 報 主 茥と分げつの生長の相互関係. 日作紀 $57: 496-504$.

花田毅一 1977. 水稲に扮ける分げつ芽の分化ならびに発育に関する 研究. 東京教育大学農紀要 $23: 43-137$.

星川清親 1975. イネの生長. VII 分げつ. 農文協, 東京. 177.

片山佃 1951. 稲. 麦の分睬研究. 稲・麦の分藥秩序に関する研究. 養 賢堂, 東京.
松葉捷也 1988. イネの茎葉生育の規則性に関する発育形態学的研究. 第 2 報 分げつの出現停止の規則性と最大分げつ数. 日作紀 $57: 599$ -607 .

松葉捷也 1996. イネの茥葉生育の規則性に関する発育形態学的研究. 第 6 報 主程と各 1 次分げつ芽の間における葉原基の分化・発育 の規則的関係. 日作紀 $65: 618-625$.

松島省三 1959 稲作の理論と技術. 第 3 章 穂数はどうして決まるか. 養賢堂, 東京. $29-30$.

三本弘乗 1968. 新しい稲作技術. 稲の深層追肥. 9 穂数はどのように して増やすか. 全農教, 東京. $134-135$.

西川五郎・花田毅一 1959. 作物の分枝性に関する研究. 第 1 報 播種 密度を異にした水稲苗に打ける分けつの分化及び発達について. 日作紀 $28: 191-193$.

大江真道 ・ 後藤雄佐 ・ 星川清親 1994. 深水処理が水稲分げつの出現 に及ぼす影響.日作紀 $63: 576-581$.

大江真道・山口裕文 2000 . ノビエにみられる分げつ型の特徵につい て.近畿作育研究 $45: 39-41$.

大江真道 · 三本弘乗 2002. 水稲の生育制御を目的とした深水処理適 期の検討. 日作紀 $71: 335-342$.

佐藤庚 1952. 水稲主稈における葉及び節間の伸長生長について（予 報). 日作紀 $21: 75-76$.

関谷福司 1977. 水稲幼作物の分けつ原基および分けつ芽に関する研 究. 第 12 報 分けつ原基拉よび分けつ芽の分化および生長につい て.日作紀 $46: 474-482$. 